\title{
On the Fossil Wood Flora of Wadi Ankebieh, Egypt, with Two New Records
}

\author{
Mona H. Darwish ${ }^{*}$, Marwah M. Kamal El-Din ${ }^{* *}$ and \\ W. E. El-Saadawi* \\ *Department of Botany, Women College Art, Science and \\ Education, and ${ }^{* * *}$ Department of Botany, Faculty of Science, \\ University of Ain Shams, Cairo, Egypt.
}

\begin{abstract}
7 FOSSIL dicot wood species (Dichrostachyoxylon royaderum-Fabaceae and Ficoxylon cretaceum-Moraceae) are reported and described for the first time from the Oligocene of Wadi Ankebieh in Egypt. Comments are made on the distribution of the fossil wood flora of Wadi Ankebieh in Egypt, other African countries, the world and on the palaeoclimate under which the trees had lived.
\end{abstract}

Keywords: Dichrostachyoxylon, Egypt, Fabaceae, Ficoxylon, Moraceae, Oligocene, Wadi Ankebieh.

Wadi Ankebieh (or Anqabiya) is one of the Oligocene fossil wood sites in Egypt (Kräusel, 1939 and Issawi et al., 1999). It belongs to the Gebel Ahmar Formation (Fourtau, 1894; Barron, 1907 and Shukri, 1954). There is only one earlier report (Kräusel, 1939) on fossil woods [Bombacoxylon owenii (Carruthers) Gottwald (Malvaceae-Bombacoideae), Detarioxylon aegyptiacum (Unger) Louvet (Fabaceae-Caesalpinioideae) and Terminalioxylon primigenium (Schenk) Mädel-Angeliewa and Müller-Stoll (Combretaceae)] from this site, which lies in the northern part of the Eastern Desert, about $34 \mathrm{~km}$ to the east of Cairo on the southern side of the Cairo-Suez Desert Road (Fig. 1) (Abd Allah, 1988). Only trunks were found; no roots, leaves or other organs. The lithostratigraphic section exposed in the Gebel Ahmar Formation appears as: vividly coloured sands and gravels with cylindrical pipes etc. Limits are: underlies the basalt flows and intrusions of the marine Miocene and overlies unconformably the Upper Eocene (Shukri 1954 and Said 1971).

The aim of this paper is the furtherance of our knowledge about the fossil woods of Wadi Ankebieh.

\section{Materials and Methods}

Four wood specimens were collected, about ten years ago, from the site. They range between $10-30 \mathrm{~cm}$ in length and $5-10 \mathrm{~cm}$ in diameter. Ground thin sections of cross, tangential and radial surfaces were prepared according to the

*Corrseponding author :E-mail addresses: monahd2000@ yahoo.com, 
method described by Andrews (1961) and Kamal El-Din (1996). The specimens and the prepared slides are numbered from 1WA to 4WA (WA refers to Wadi Ankebieh; the study area) and deposited in the palaeobotanical collection of the Department of Botany, Ain Shams University.

The descriptions followed the International Association of Wood Anatomists Committee recommendations (IAWA Committee 1989). Affinities were determined by consulting reference works which will be mentioned where appropriate. The Vulnerability Index (V) was calculated using the Carlquist (1977) equation. Relevant fossil wood genera were discussed in light of the comprehensive survey of fossil woods (Gregory et al., 2009). Systematic assignment follows the APG III (2009).

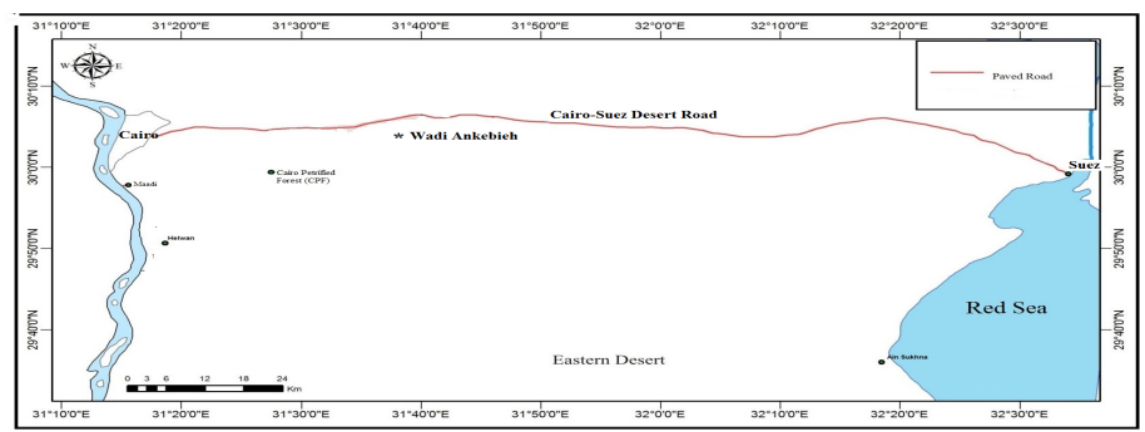

Fig. 1. Map showing location of the study area (Wadi Ankebieh) and some relevant landmarks.

\section{Results and Description}

Microscopic examination showed that specimens no. 2WA \& 4WA belonged to Dichrostachyoxylon royaderum (Fabaceae-Mimosoideae), specimen no. 3WA to Ficoxylon cretaceum (Moraceae), while the fourth specimen (no. 1WA) could not be identified being badly preserved, however it belongs to the dicots. Dichrostachyoxylon royaderum and Ficoxylon cretaceum are new records to the site which is now known to contain five species in four families. The two new records are described, illustrated and discussed in this paper.

Order: Fabales

Family: Fabaceae

Subfamily: Mimosoideae

Genus: Dichrostachyoxylon Müller-Stoll and Mädel 1967

Species: Dichrostachyoxylon royaderum Privé 1969

Growth rings distinct, marked by marginal parenchyma. Wood diffuseporous. Vessels solitary and in radial multiples of 2-3. Vessels round to oval in cross section; tangential diameter $110-170 \mu \mathrm{m}$ (mean $140 \mu \mathrm{m})$, radial diameter 140-220 $\mu \mathrm{m}$ (mean $180 \mu \mathrm{m}$ ). Vessels 3-8 per sq. mm. Perforation plates simple

Egypt. J. Bot. 56, No. 3 (2016) 
with oblique end walls, intervessel pits alternate. Mean vessel element length $330 \mu \mathrm{m}$; short to medium in length. Fibres non-septate and thin- to thick-walled. Axial parenchyma vasicentric, weakly aliform, marginal parenchyma bands and diffuse parenchyma cells. Rays 1-5 seriate; homocellular, composed of procumbent cells.

Order: Rosales

Family: Moraceae

Genus: Ficoxylon Kaiser 1880

Species: Ficoxylon cretaceum Schenk 1883

Growth rings indistinct. Wood diffuse-porous. Vessels solitary and in radial multiples of 2-3 (4). Vessels round to oval in cross section; tangential diameter 100-150 $\mu \mathrm{m}$ (mean $120 \mu \mathrm{m}$ ), radial diameter 220-275 $\mu \mathrm{m}$ (mean $240 \mu \mathrm{m}$ ). Vessels 3-9per sq. mm. Perforation plates simple with horizontal to oblique end walls, intervessel pits alternate. Mean vessel element length $350 \mu \mathrm{m}$. Fibres in bands alternating with parenchyma bands (are more or less of the same thickness); libriform non-septate with simple to minutely bordered pits. Axial parenchyma in regular bands more than six cells wide; 4-8 cells per strand and crystalliferous strands present. Rays mostly 2-3 cells wide (a few uniseriate), 10-20 cells in hight, homocellular composed of procumbent cells.

\section{Distribution, Comparisons and Discussion}

The family Fabaceae has about 100 fossil wood genera worldwide (Gregory et al., 2009). And fossil legume wood genera and species described in the literature outnumber those of any other dicot family (Wheeler and Manchester, 2002; Kamal El-Din and El-Saadawi, 2004; El-Saadawi et al., 2011 and Kamal El-Din et al, 2015). The genus Dichrostachyoxylon was established by Müller-Stoll and Mädel in the year 1967 and fifteen species have since been described worldwide (Gregory et al., 2009 and Ziada, 2014). Species of Dichrostachyoxylon were spread in the Palaeogene (Palaeocene, Eocene and Oligocene) and Neogene (Miocene and Pliocene) of four continents (Africa, Asia, Europe and North America) (Gregory et al., 2009). In Egypt, genus Dichrostachyoxylon was recorded, for the first time, from the Oligocene of Gebel Qatrani by Bkhat (2012) but he mentioned no species. Two years later Ziada (2014) reported on D. palaeonyassanum, D. royaderum and D. zirkelii from the Oligocene of the Cairo Petrified Forest (CPF). Outside Egypt the species D. royaderum is only known from the Oligocene of France (Privé, 1969).

There are slight anatomical differences between the samples of $D$. royaderum described from Wadi Ankebieh (this work), the CPF in Egypt (Ziada, 2014) and France (Privé, 1969) (Table 1). 
TABLE 1. Xylotomical comparison of specimens of $D$. royaderum from Wadi Ankebieh (this paper), the Cairo Petrified Forest (CPF) (Ziada, 2014) and France (Privé, 1969).

\begin{tabular}{|c|c|c|c|}
\hline \multirow[t]{2}{*}{ Features } & \multicolumn{2}{|c|}{ Egypt } & \multirow[t]{2}{*}{ France } \\
\hline & Wadi Ankebieh & CPF & \\
\hline Growth rings & Distinct & Distinct & Distinct \\
\hline Vessels & $\begin{array}{l}\text { Solitary \& in radial } \\
\text { multiples of } 2-3\end{array}$ & $\begin{array}{l}\text { Solitary \& in radial } \\
\text { multiples of } 2-3\end{array}$ & $\begin{array}{c}\text { Solitary \& in radial } \\
\text { multiples of } 2-3\end{array}$ \\
\hline $\begin{array}{l}\text { Vessel mean } \\
\text { tangential } \\
\text { diameter }\end{array}$ & $\begin{array}{l}110-170 \mu \mathrm{m} \\
\text { (av. } 140 \mu \mathrm{m})\end{array}$ & $\begin{array}{l}125-190 \mu \mathrm{m} \\
\text { (av. } 155 \mu \mathrm{m})\end{array}$ & $\begin{array}{c}60-145 \mu \mathrm{m} \\
\text { (av. } 105 \mu \mathrm{m})\end{array}$ \\
\hline Vessel frequency & $3-8 / \mathrm{mm}^{2}$ & $2-7 / \mathrm{mm}^{2}$ & $10-20 / \mathrm{mm}^{2}$ \\
\hline $\begin{array}{l}\text { Axial } \\
\text { parenchyma }\end{array}$ & $\begin{array}{c}\text { Diffuse, } \\
\text { vasicentric, weakly } \\
\text { aliform, marginal } \\
\text { bands }\end{array}$ & $\begin{array}{c}\text { Diffuse, } \\
\text { vasicentric, weakly } \\
\text { aliform, marginal } \\
\text { bands }\end{array}$ & $\begin{array}{l}\text { Diffuse, vasicentric, } \\
\text { weakly aliform, } \\
\text { marginal bands }\end{array}$ \\
\hline Ray width & $1-5$ & $1-5$ & $1-5$ \\
\hline Ray composition & Homocellular & Homocellular & Homocellular \\
\hline
\end{tabular}

It is clear from Table 1 that specimens of D. royaderum from the two Egyptian sites are almost identical and those from France differ only in vessel frequency (being higher in France) and vessel mean tangential diameter (being narrower in France), indicating a cooler palaeoclimate for the French specimens.

Fabaceae includes about 700 extant genera and 20.000 extant species worldwide (Wojciechowski, 2003). It is the third largest family of the flowering plants and its members are found in tropical rain forests to desert and alpine tundra (Wojciechowski, 2003). Dichrostachys; the "nearest living relative" of Dichrostachyoxylon has 9 species spread in tropical areas of three continents: Africa, America and Asia (Mabberley, 1987). i.e., similar in its distribution to its ancestor (Dichrostachyoxylon) except that the latter occurred also in Europe (Gregory et al., 2009).

The family Moraceae has ten fossil wood genera worldwide (DupéronLaudoueneix and Dupéron, 1995 and Gregory et al., 2009; Bernabei et al., 2010 and Franco, 2010 and Boonchai et al., 2015). The ages of these genera range from the Upper Cretaceous to the Pliocene (Collinson, 1989; Gregory et al., 2009), with most occurrences reported from the Oligocene to Pliocene (Gregory et al., 2009). Only two of these 10 genera, i.e., Ficoxylon and Myrianthoxylon were reported from Africa (Dupéron-Laudoueneix and Dupéron, 1995; Kamal El-Din, 2003 and

Egypt. J. Bot. 56, No. 3 (2016) 
Gregory et al., 2009). Genus Ficoxylon has over 15 species worldwide (Africa, Asia, Europe, North America and South America) (Gregory et al., 2009 and JollySaad et al., 2010) ranging in age from Cretaceous to Miocene/Pliocene. The species F. cretaceum (recorded here from Wadi Ankebieh) is already known from Africa (Egypt, Ethiopia and Tunisia) and South America (Colombia) (DupéronLaudoueneix and Dupéron, 1995; Gregory et al., 2009).

There are slight anatomical differences between the samples of F. cretaceum described here from Wadi Ankebieh and those described from different sites in Egypt (Kräusel, 1939), Farafra Oasis in Egypt (Kamal El-Din, 2003), Ethiopia (Lemoigne et al., 1974) and Tunisia (Fessler-Vrolant, 1979) (Table 2). It has to be mentioned that the description of the samples from Colombia is not available to the present authors, therefore not included in Table 2.

TABLE 2. Xylotomical comparison of specimens of $F$. cretaceum from Wadi Ankebieh (this paper), different sites in Egypt (Kräusel, 1939), Farafra Oasis (Kamal El-Din, 2003), Ethiopia (Lemoigne et al., 1974) and Tunisia (Fessler-Vrolant, 1979).

\begin{tabular}{|l|c|c|c|c|c|}
\hline \multirow{2}{*}{ Features } & \multicolumn{3}{|c|}{ Egypt } & \multirow{2}{*}{ Ethiopia } & Tunisia \\
\cline { 2 - 5 } & $\begin{array}{c}\text { Wadi } \\
\text { Ankebieh }\end{array}$ & $\begin{array}{c}\text { Different } \\
\text { sites }\end{array}$ & $\begin{array}{c}\text { Farafra } \\
\text { Oasis }\end{array}$ & & \\
\hline $\begin{array}{l}\text { Vessel mean } \\
\text { tangential diameter }\end{array}$ & $\begin{array}{c}100-150 \mu \mathrm{m} \\
(\text { av. } 120 \mu \mathrm{m})\end{array}$ & $\begin{array}{c}80-260 \\
\mu \mathrm{m}\end{array}$ & $\begin{array}{c}65-165 \mu \mathrm{m} \\
(\text { av. } 140 \mu \mathrm{m})\end{array}$ & $\begin{array}{c}90-350 \\
\mu \mathrm{m}\end{array}$ & $\begin{array}{c}70-136 \\
\mu \mathrm{m}\end{array}$ \\
\hline Vessel frequency & $3-9 / \mathrm{mm}^{2}$ & $6-12 / \mathrm{mm}^{2}$ & $4-8 / \mathrm{mm}^{2}$ & & $4-9 / \mathrm{mm}^{2}$ \\
\hline $\begin{array}{l}\text { Mean vessel } \\
\text { element length }\end{array}$ & $350 \mu \mathrm{m}$ & $400 \mu \mathrm{m}$ & $385 \mu \mathrm{m}$ & - & $300 \mu \mathrm{m}$ \\
\hline
\end{tabular}

The extant genera of the family Moraceae are found mainly in subtropical to tropical regions with a few in temperate regions (Boonchai et al., 2015). The family includes 53extant genera and 1.500 extant species (Elpel, 2013). Ficus; the "nearest living relative" of Ficoxylon is the largest genus of the Moraceae with more than 900 species in Africa, America and Australasia (Koek-Noorman et al., 1984). However, it is more restricted in distribution than its ancestor (Ficoxylon) which was spread in five continents (Africa, Asia, Europe, North America and South America). The distribution of the five species of Wadi Ankebieh in Egypt is given in Table 3.

As shown in Table 3 there are 38 Egyptian sites from which, at least, one of the five species was reported. Table 3 shows also that the 5 species occur together in only two out of the 38 sites, i.e. Wadi Ankebieh and the CPF (which lies at a distance of about $20 \mathrm{Km}$ from Wadi Ankebieh, (Fig. 1). Four of the five species of Wadi Ankebieh are known from two other sites: Wadi Faregh and West of Giza 
Pyramids. Other sites include only one to three of the five species. Table 3 shows also that the wood species reported from Wadi Ankebieh except D. royaderum are wide spread in Egypt being reported in 27 (B. owenii), 18 (D. aegyptiacum), 17 (T. primigenium) and 11 (F.cretaceum) sites ranging in age from Cretaceous to Quaternary (Kräusel, 1939; Kamal El-Din, 2002, 2003; El-Saadawi et al., 2011, 2014 and Ziada, 2014; Kamal El-Din et al., 2015). Most of these sites are in the Western and Eastern Deserts while a few are in Nile Delta, Nile Valley and Sinai.

Bombacoxylon owenii is not only the most widespread species in Egypt but also in Africa ( 7 countries) and in other continents (Asia and Europe) (Table 4) ranging in age from Cretaceous to Quaternary (Dupéron-Laudoueneix and Dupéron, 1995; Kamal El-Din, 2002; Gregory et al., 2009 and El-Saadawi et al., 2014). D. aegyptiacum is recorded from only Africa (6 countries) (Table 4) ranging in age from Eocene to Quaternary (Dupéron-Laudoueneix and Dupéron, 1995; Kamal El-Din and Refaat, 2001; El-Saadawi et al., 2011 and Kamal ElDin et al., 2015). D. royaderum is reported from the Oligocene of two continents (Table 4) (Africa, one country) (Ziada, 2014) and Europe, one country (Gregory et al., 2009)). F. cretaceum is recorded from four countries in Africa and from one country in South America (Table 4) ranging in age from Cretaceous to Pliocene (Dupéron-Laudoueneix and Dupéron, 1995; Kamal ElDin, 2003 and Gregory et al., 2009). T. primigenium is reported from only Africa (3 countries) (Table 4) ranging in age from Oligocene to Miocene (Dupéron-Laudoueneix and Dupéron, 1995; El-Saadawi and Kamal El-Din, 2004 and El-Saadawi et al., 2014).

The $\mathrm{V}$ values (mean tangential diameter/mean number of vessels per square $\mathrm{mm}$ ) for $D$. royaderum and $F$. cretaceum (described here) are 25 and 20 respectively. The $\mathrm{V}$ values of the three other species reported earlier from Wadi Ankebieh were not mentioned in the original publication (Kräusel, 1939) but are calculated here for specimens of B. owenii and D. aegyptiacum as described from the CPF by Ziada (2014) and for specimens of $T$. primigenium as described from Widan El-Faras by El-Saadawi and Kamal El-Din (2004). The $\mathrm{V}$ values of the 3 species are 42.5, 40 and 25 respectively. These high $\mathrm{V}$ values of the 5 species suggest that these woods likely grew in an area of low water stress (Carlquist, 1977). These wood species show features that are more common in the tropics than in temperate floras such as: abundant axial parenchyma (banded, vasicentric and diffuse), diffuse-porous wood, medium to slightly large sized vessels and low number of vessels per sq. mm (Wheeler and Baas, 1991; Wheeler, 2001; Alves and Angyalossy-Alfonso, 2002). The Oligocene palaeoclimate of Wadi Ankebieh or the site of growth in case these woods had been transported is suggested to be tropical or subtropical which confirms earlier (El-Saadawi et al., 2011, 2014 and Ziada, 2014) assumptions regarding the palaeoclimate of the growth site of these trees. 
TABLE 3 . The distribution the fossil wood flora of Wadi Ankebieh in other Egyptian sites. (based on: Kräusel, 1939; Youssef, 1993; Kamal El-Din and Refaat, 2001; Kamal El-Din, 2002; Kamal El-Din, 2003; ElSaadawi and Kamal El-Din, 2004; El-Saadawi et al., 2011, 2014; Ziada, 2014; Kamal El-Din et al., 2015).

\begin{tabular}{|c|c|c|c|c|c|c|}
\hline Fites & B.owenii & \begin{tabular}{|c|} 
D. \\
aegyptiacum
\end{tabular} & $\begin{array}{c}\text { D. } \\
\text { royaderum }\end{array}$ & $\begin{array}{c}F . \\
\text { cretaceum }\end{array}$ & \begin{tabular}{|c|}
$T$. \\
primigenium
\end{tabular} & $\begin{array}{c}\text { total } \\
\text { no. of } \\
\text { species/ } \\
\text { site }\end{array}$ \\
\hline Wadi Ankebieh & + & + & + & + & + & 5 \\
\hline Abou Roasch & & & & + & & 1 \\
\hline Bahariya & + & + & & & & 2 \\
\hline Bir El-Fahme & + & + & & & & 2 \\
\hline Bir Lebuk & + & & & + & + & 3 \\
\hline Birket Qerun & + & + & & & + & 3 \\
\hline $\begin{array}{l}\text { Cairo-Bahariya } \\
\text { Oasis Desert Road }\end{array}$ & + & & & & & 1 \\
\hline CPF & + & + & + & + & + & 5 \\
\hline Der Baramus & + & & & & + & 2 \\
\hline Farafra Oasis & & & & + & & 1 \\
\hline Fayum & + & + & & & + & 3 \\
\hline Garet Aujan & + & & & & & 1 \\
\hline Gebel Ahmer & + & + & & & + & 3 \\
\hline Gebel Amuna & & + & & & + & 2 \\
\hline Gebel Dera in Suez & + & & & & & 1 \\
\hline $\begin{array}{l}\text { Gebel El-Khashab } \\
\text { (NPF) }\end{array}$ & + & & & + & & 2 \\
\hline $\begin{array}{l}\text { Gebel El-Khashab } \\
\text { (SPF) }\end{array}$ & + & + & & & + & 3 \\
\hline $\begin{array}{l}\text { Gebel Garra west } \\
\text { Aswan }\end{array}$ & & & & + & & 1 \\
\hline Gebel Geneffe & + & & & & & 1 \\
\hline Gebel Giaffara & & & & + & + & 2 \\
\hline $\begin{array}{l}\text { Gebel Hadahid in } \\
\text { Sinai }\end{array}$ & & + & & & & 1 \\
\hline Gebel Qatrani & + & + & & & + & 3 \\
\hline Gebel Ruzza & + & & & & + & 2 \\
\hline Gebel Shabraweet & + & & & & & 1 \\
\hline Helwan & & + & & & & 1 \\
\hline Moghara & + & + & & & & 2 \\
\hline Mokattam & + & + & & & + & 3 \\
\hline Siwa Oasis & + & & & & & 1 \\
\hline Tanta & & + & & & & 1 \\
\hline Turra & + & & & & + & 2 \\
\hline Wadi Dugla & & + & & & & 2 \\
\hline Wadi Faregh & + & + & & + & + & 4 \\
\hline Wadi Natrun & + & & & & & 1 \\
\hline Wadi Schait & + & & & & & 1 \\
\hline Wadi Sanur & + & & & & & 1 \\
\hline $\begin{array}{l}\text { West of Giza Pyramids } \\
\text { (Giza Pyramids) }\end{array}$ & + & + & & + & + & 4 \\
\hline Widan El-Faras & & & & & + & 1 \\
\hline $\begin{array}{l}\text { Zone between Cairo } \\
\text { and Suez }\end{array}$ & & & & + & & 1 \\
\hline $\begin{array}{l}\text { total no. of sites for } \\
\text { each species }\end{array}$ & 27 & 18 & 2 & 11 & 17 & \\
\hline
\end{tabular}


TABLE 4. The distribution the fossil wood flora of Wadi Ankebieh in different continents of the world.

\begin{tabular}{|c|c|c|c|c|}
\hline Continents & Africa & Asia & Europe & $\begin{array}{c}\text { South } \\
\text { America }\end{array}$ \\
\hline B. owenii & $\begin{array}{l}\text { Egypt, Libya, Tunisia, } \\
\text { Algeria, Rio de Oro, } \\
\text { Ethiopia and Somalia }\end{array}$ & $\begin{array}{l}\text { Jordan or } \\
\text { Israel, } \\
\text { Pakistan and } \\
\text { Thailand }\end{array}$ & $\begin{array}{c}\text { France, } \\
\text { Germany, } \\
\text { Sardinia and } \\
\text { UK }\end{array}$ & \\
\hline D. aegyptiacum & $\begin{array}{c}\text { Egypt, Libya, Tunisia, } \\
\text { Algeria, Rio de Oro } \\
\text { and Somalia }\end{array}$ & & & \\
\hline D. royaderum & Egypt & & France & \\
\hline F. cretaceum & $\begin{array}{c}\text { Egypt, Tunisia, Ethiopia } \\
\text { and Mali }\end{array}$ & & & Colombia \\
\hline T. primigenium & $\begin{array}{l}\text { Egypt, Libya and } \\
\text { Somalia }\end{array}$ & & & \\
\hline
\end{tabular}

Acknowledgements: Special thanks to Dr. Osman Abd El-Ghany (Geology Department, Faculty of Science Ain Shams University) for collecting the specimens which were the material of this paper. Thanks to Prof. Dr. Magdy Abd Al-Hameed Al-Sersy \& Mrs. Enas Farghly (Geography Department, Women's College for Science, Arts and Education, Ain Shams University) for there kind help with the map. Thanks to Prof. Dr. Sameer Awad (Geology Department, Faculty of Science, Ain Shams University) for providing some relevant papers. Thanks are also due to Mr. Mohamed Farag (Botany Department, Faculty of Science, Ain Shams University) for his kind help with the digital plates. 

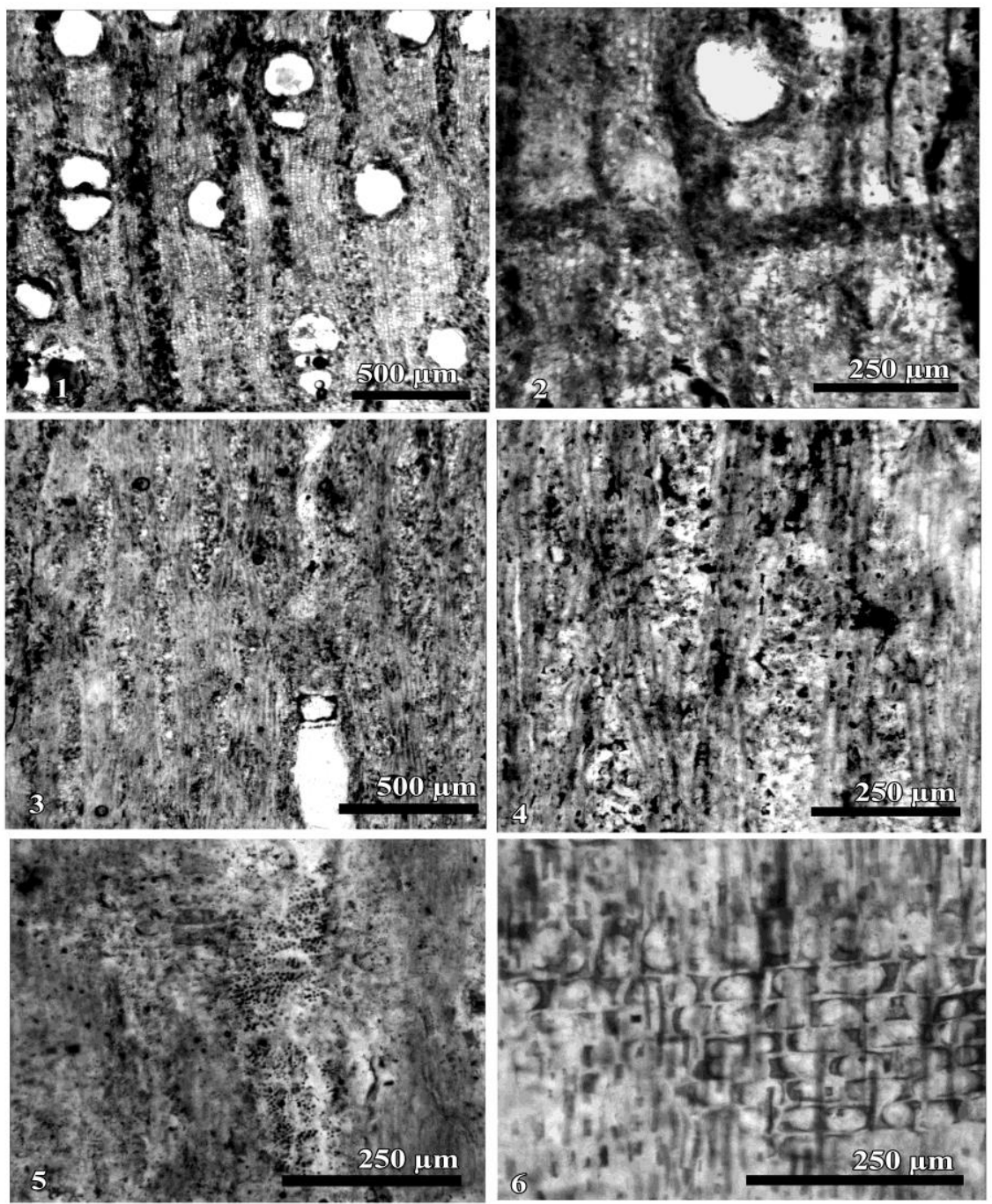

Plate I. Dichrostachyoxylon royaderum 1: Cross section showing diffuse-porous wood, solitary vessels and 2-3 multiples of vessels; 2: Cross section magnified to show one growth ring and diffuse parenchyma cells; $3 \& 4$ : Tangential longitudinal section showing rays; 5: Longitudinal section showing alternate intervessel pits; 6: Radial longitudinal section showing homocellular rays. 

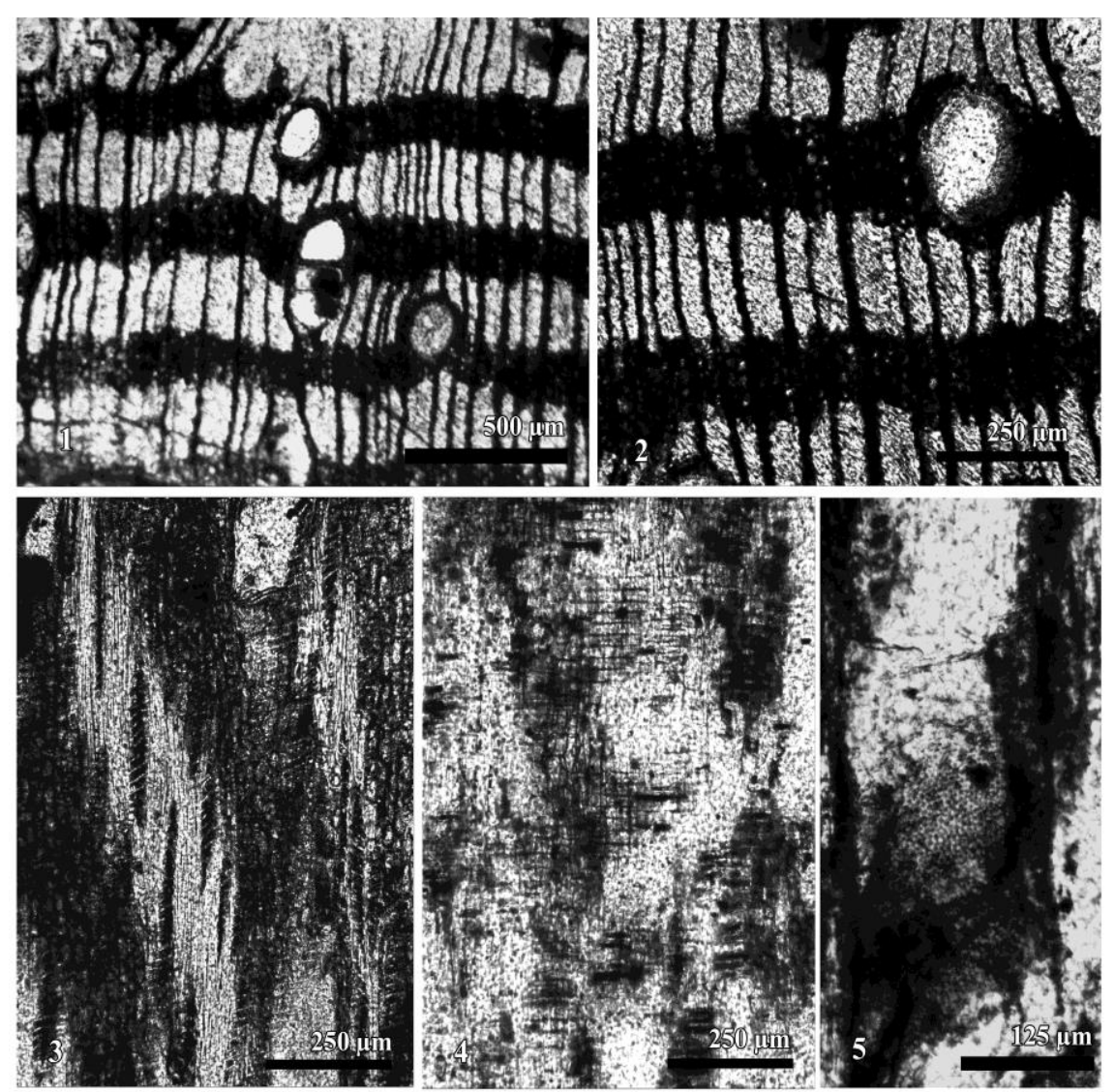

Plate II. Ficoxylon cretaceum 1: Cross section showing diffuse-porous wood and regular bands of parenchyma; 2: Cross section magnified to show fibres bands alternating with parenchyma bands; 3: Tangential longitudinal section showing rays; 4: Radial longitudinal section showing homocellular rays; 5: Longitudinal section showing alternate intervessel pits.

\section{References}

Abd Allah, A.M. (1988) Structural setting of the area west and southwest of Gebel Qattamia. M.Sc. Thesis. Geol. Dept., Fac. of Sci., Ain Shams Univ., Cairo, Egypt, pp. $1-117$.

Alves, E.S. and Angyalossy-Alfonso, V. (2002) Ecological trends in the wood anatomy of some Brazilian species. 2. Axial parenchyma, rays and fibers. IAWA J., 23, 391-418.

Andrews, H.N. (1961) “Studies in Palaeobotany” Wiley, New York and London, pp. 1-487.

APG III. (2009) An update of the Angiosperm Phylogeny Group classification for the orders and families of flowering plants. Bot. J. Linn. Soc., 161, 105-121. 
Barron, T. (1907) The Topography and Geology of the District between Cairo and Suez. Survey Department of Egypt, Cairo, pp. 1-133.

Bernabei M, Pallozzi B, Ceccon L, Mietto P and Roghi G. (2010) Middle Eocene (Bartonian) Ficus from Monte di Malo (Vicenza - Italy). IAWA J., 31, 353-362.

Bkhat, H. (2012) Studies on the fossil mangroves of the Western Desert of Egypt. Ph.D. Thesis, Bot. Dept., Fac. of Sci., Ain Shams Univ., Cairo, Egypt, pp. 1-141.

Boonchai, N., Manchester, S.R., and Wheeler, E.A. (2015) Welkoetoxylon ultiseriatum: fossil moraceous wood from the Eocene Green River Formation, Wyoming, U. S. A. IAWA J., 36, 158-166.

Carlquist, S. (1977) Ecological factors in wood evolution. a floristic approach. Amer. J. Bot., 64 (7), 887-896.

Collinson M.E. (1989) The fossil history of the Moraceae, Urticaceae (including Cecropiaceae), and Cannabaceae. In: Crane PR and Blackmore S (Eds.), "Evolution, systematics and fossil history of the Hamamelidae". Vol. 2. Higher Hamamelidae. Systematics Association Special Volume 40B, 319-339. Clarendon Press, Oxford.

Dupéron-Laudoueneix, M. and Dupéron, J. (1995) Inventory of Mesozoic and Cenozoic woods from Equatorial and North Equatorial Africa. Rev. Palaeobot. Palynol., 84, 439-480.

Elpel, T.J. (2013) "Botany in a Day The Patterns Method of Plant Identification". An herbal field guide to plant families of North America", $6^{\text {th }}$ ed. HOPS Press, LLC.

El-Saadawi, W.E. and Kamal El-Din, M.M. (2004) Terminalioxylon species from Gebel Qatrani Formation at Widan El-Faras, Fayum, Egypt. Taeckholmia, 24, 63-78.

El-Saadawi, W., Kamal El-Din, M.M., Attia, Y. and El-Faramawi, M.W. (2011) The wood flora of the Cairo Petrified Forest, with five paleogene new legume records for Egypt. Rev. Palaeobot. Palynol., 167, 184-195.

El-Saadawi, W. ,Kamal El-Din, M.M., Wheeler, E., Osman, R., El-Faramawi, M.W. and El-Noamani, Z. (2014) Early miocene woods of Egypt. IAWA J., 35, 35-50.

Fessler-Vrolant, C. (1979) Étude paléoxylologique de l'Afrique du Nord: sur un Échantillon de Ficoxylon cretaceum Schenk du Djebel Cherichira (Tunisie). 104ème Congr. Nat. des Soc. Sav., Bordeaux, Sci. fasc., I, 301-311.

Fourtau, R. (1894) Etude geologique sur le Gebel Ahmar. Bulletin de l'Institute Egyptien, ser., 3 (5), 377-386.

Franco, M.J. (2010) Soroceaxylon entrerriensis gen. et sp. nov. (Moraceae) de la Formación Ituzaingó (Plioceno-Pleistoceno), Cuenca del río Paraná, Argentina. Rev. Mex. Cienc. Geol., 27, 508-519. 
Gregory, M., Poole, I. and Wheeler, E.A. (2009) Fossil dicot wood names an annotated list with full bibliography. IAWA J., supplement 6, 1-220.

IAWA Committee (1989) IAWA list of microscopic features for hardwood identification. IAWA Bull. n.s., 10, 219-332.

Issawi, B., El Hinnawi, M., Francis, M. and Mazhar, A. (1999) The Phanerozoic geology of Egypt a geodynamic approach. The Egyptian Geological Survey: Special Publication, 76, pp. 1-462.

Jolly-Saad, M.-C., Dupéron-Laudoueneix, M., Dupéron, J. and Bonnefille, R. (2010) Ficoxylon sp., a fossil wood of 4.4 Ma (Middle Awash, Ethiopia). C. R. Palevol, 9, 1-4.

Kaiser, P.E. (1880) Ficoxylon bohemicum, ein neues fossils Laubholz. Zeitschr. Gesamt. Naturw., 53, 309-317.

Kamal El-Din, M.M. (1996) Studies on a petrified wood at Gebel El-Khashab, Western Desert, Egypt. M.Sc. Thesis. Bot. Dept., Fac. of Sci., Ain Shams Univ., Cairo, Egypt, pp. 1-150.

Kamal El-Din, M.M. (2002) Bombacoxylon owenii (Carr.) Gottwald from Gebel Shabraweet, Eastern Desert, Egypt. Taeckholmia , 22, 91-99.

Kamal El-Din, M.M. (2003) Petrified wood from the Farafra Oasis, Egypt. IAWA J. 24, 163-172.

Kamal El-Din, M.M. and El-Saadawi, W.E. (2004) Two Leguminosae woods from the Miocene of Gebel Ruzza, Egypt. IAWA J., 25, 471-483.

Kamal El-Din, M.M. and Refaat, A.A. (2001) Detarioxylon aegyptiacum (Leguminosae), from Lower Miocene marine sediments in Southern Sinai. Taeckholmia , 21, 103-114.

Kamal El-Din, M.M., Darwish, M. and El-Saadawi, W. (2015) Novelties on Miocene woods from Egypt with a summary on African fossil woods of Fabaceae, Malvaceae and Dipterocarpaceae. Palaeontographica B, 292, 173-199.

Koek-Noorman, J., Topper, S.M. and ter Welle, B.J. (1984) The systematic wood anatomy of the Moraceae (Urticales): III. Tribe Ficeae. IAWA Bull. n.s. 5, 330-334.

Kräusel, R. (1939) Ergebnisse der Forschungsreisen Prof. E. Stromers in den Wüsten Ägyptens, IV. Die fossilen Floren Ägyptens: Die Fossilen Pflanzen Ägyptens. E-L Abh. Bayer. Akad. Wiss., Math.-Nat. Abt. N. F., 47, 1-140.

Lemoigne, Y., Beauchamp, J. and Samuel, E. (1974) Etude paléobotanique des dépôts volcaniques d'âge tertiaire des bordures est et oust du système des rifts éthiopiens. Geobios, 7 (3), 267-288.

Egypt. J. Bot. 56, No. 3 (2016) 
Mabberley, D. J. (1987) "The Plant-Book: A Portable Dictionary of the Higher Plants". Cambridge University Press, Cambridge.

Müller-Stoll, W.R. and Mädel, E. (1967) Die fossilen Leguminosen-Hölzer. Eine Revision der mit Leguminosen verglichenen fossilen Hölzer und Beschreibungen älterer und neuer Arten. Palaeontogr. B 119, 95-174.

Privé, C. (1969) Sur un bois de Légumineuses du Stampien de Royat (Puy-de-Dôme). $C$. r. 94c Congr. Nat. Soc. Sav., Pau, Sci., 3, 191-205.

Said, R. (1971) Explanatory notes to accompany the geological map of Egypt. The Geological Survey of Egypt 56, 1-123.

Schenk, A. (1883) Fossile Hölzer. Palaeontographica, 30(2), 1-19.

Shukri, N.M. (1954) On cylindrical structures and colouration of Gebel Ahmar near Cairo, Egypt. Bull. Fac. Sci., Cairo Univ., 32, 1-23.

Wheeler, E.A. (2001) Fossil dicotyledonous woods from Florissant Fossil Beds National Monument, Colorado. Denver Museum of Natural \& Science, 4, 187-203.

Wheeler, E.A. and Baas, P. (1991) A survey of the fossil record for dicotyledonous wood and its significance for evolutionary and ecological wood anatomy. IAWA Bull., n. s. 12, 275-332.

Wheeler, E.A. and Manchester, S.R. (2002) Woods of the Middle Eocene Nut Beds Flora, Clarno Formation, Oregon, USA, IAWA J. Supplement 3.

Wojciechowski, M.F. (2003) Reconstructing the phylogeny of legumes (Leguminosae): an early $21^{\text {st }}$ century perspective. In: Klitgaard, B.B. and Bruneau, A. (Eds.), Advances in Legume Systematics. Higher Level Systematics, 10. Royal Botanic Gardens, Kew, pp. 535 .

Youssef, S.G. (1993) Studies on some Egyptian fossil woods. Ph.D. Thesis. Bot. Dept., Fac. of Sci., Zagazig Univ., Benha, Egypt, pp. 1-153.

Ziada, N. (2014) Palaeobotanic and palaeoclimatic studies on the Cairo Petrified Forest protected area. M.Sc. Thesis. Bot. Dept., Fac. of Sci., Ain Shams Univ., Cairo, Egypt, pp. 1-170.

(Received $14 / 2 / 2016$; accepted 19/3/2016) 


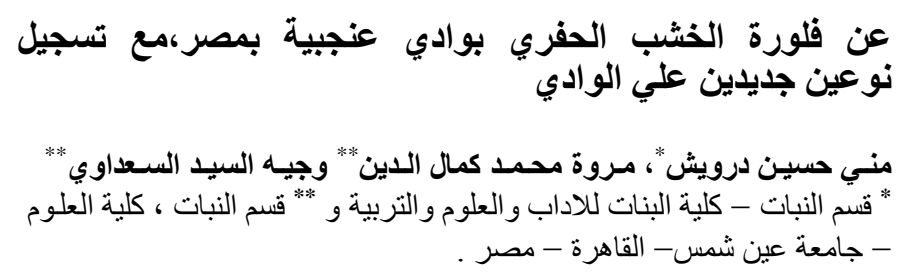

تم جمع ووصف خشب حفري من عصر الاوليجوسين ينتمي لنوع

Dichrostachyoxylon royaderum

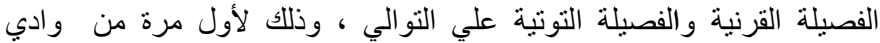

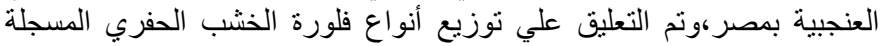

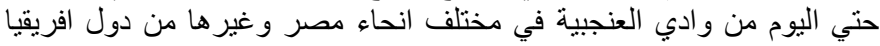

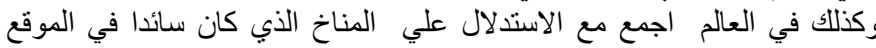

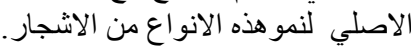

